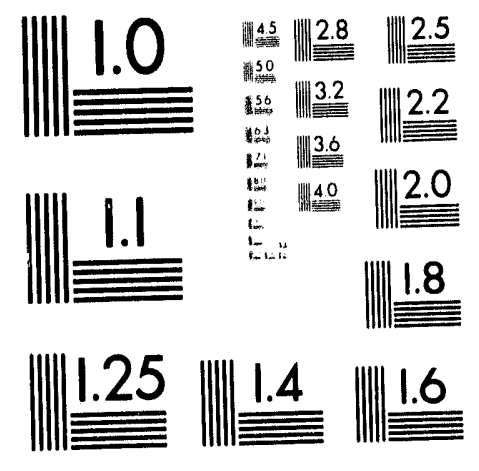



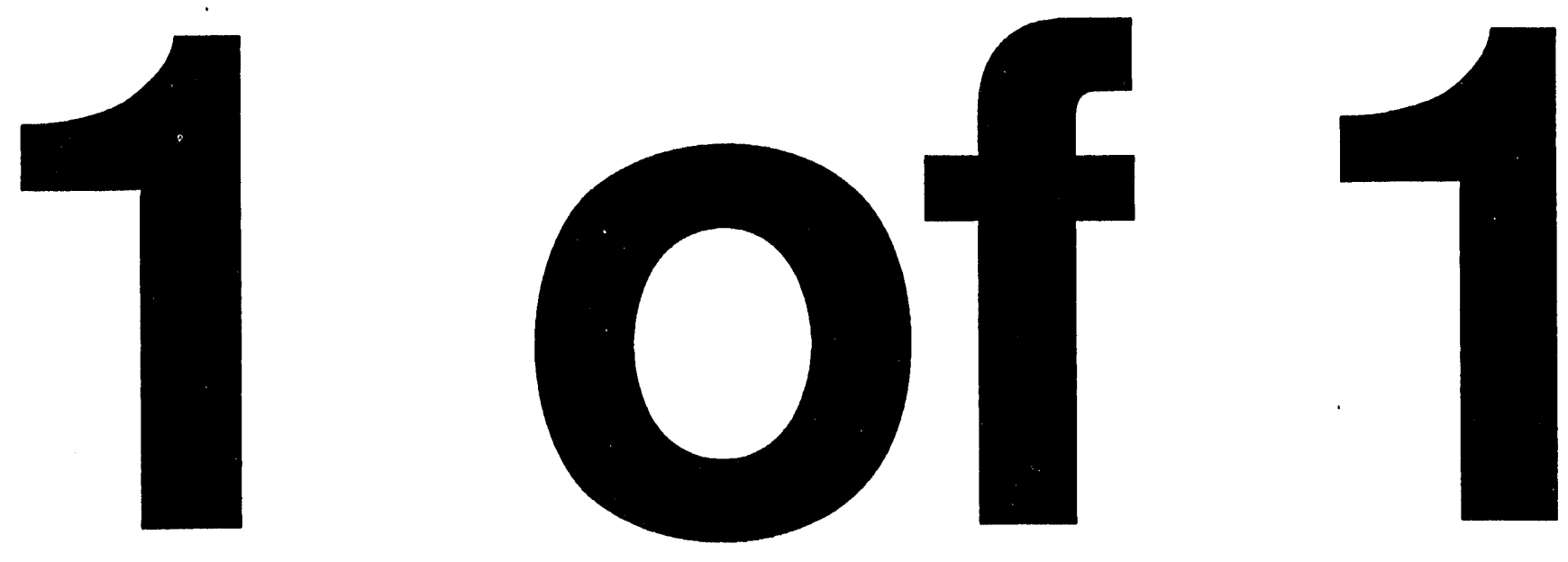


\section{Used Oil Disposal and Recycling in the United States}

by D.E. Karvelas and E.J. Daniels

Energy Systems Division,

Argonne National Laboratory, 9700 South Cass Avenue, Argonne, Illinois 60439

July 1993

Work sponsored by United States Department of Energy,

Assistant Secretary for Energy Efficiency and Renewable Energy 


\section{CONTENTS}

ACKNOWLEDGMENTS $\ldots \ldots \ldots \ldots \ldots \ldots \ldots \ldots \ldots \ldots \ldots \ldots \ldots$

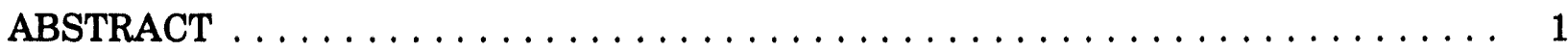

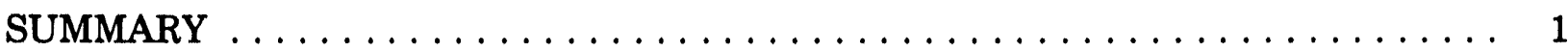

1 GENERATION OF USED OIL $\ldots \ldots \ldots \ldots \ldots \ldots \ldots \ldots \ldots \ldots \ldots$

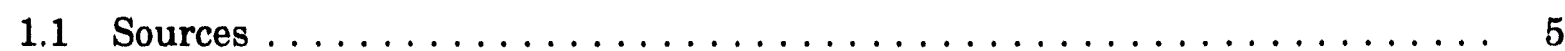

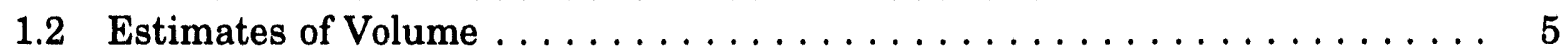

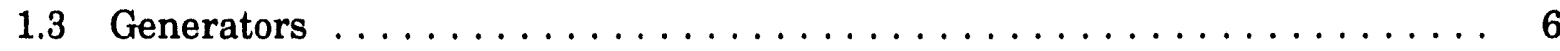

2 DISPOSITION OF USED OIL $\ldots \ldots \ldots \ldots \ldots \ldots \ldots \ldots \ldots \ldots \ldots$

2.1 Collectors/Transporters $\ldots \ldots \ldots \ldots \ldots \ldots \ldots \ldots \ldots \ldots \ldots \ldots \ldots$

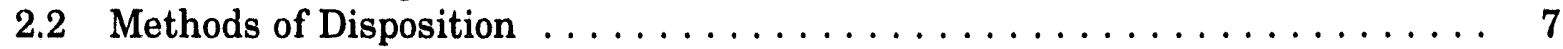

2.3 Burning Used Oil as Fuel $\ldots \ldots \ldots \ldots \ldots \ldots \ldots \ldots \ldots \ldots$

2.4 Re-Refining Used Oil $\ldots \ldots \ldots \ldots \ldots \ldots \ldots \ldots \ldots \ldots \ldots \ldots$

3 ENERGY CONSERVATION CONSIDERATIONS $\ldots \ldots \ldots \ldots \ldots \ldots \ldots$

3.1 Reprocessing Used Oil as Fuel $\ldots \ldots \ldots \ldots \ldots \ldots \ldots \ldots \ldots \ldots$

3.2 Re-Refining Used Oil as Lube Oil $\ldots \ldots \ldots \ldots \ldots \ldots \ldots \ldots \ldots \ldots$

3.3 Comparison of Reprocessing and Re-Refining $\ldots \ldots \ldots \ldots \ldots \ldots \ldots$

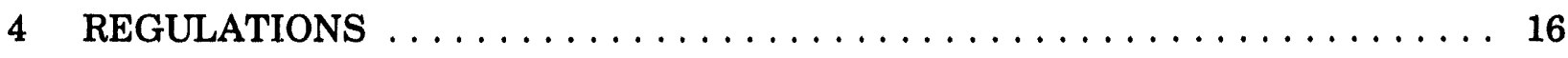

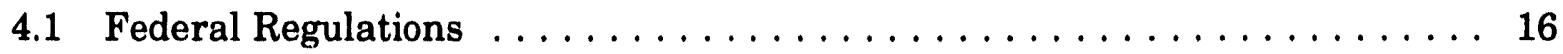

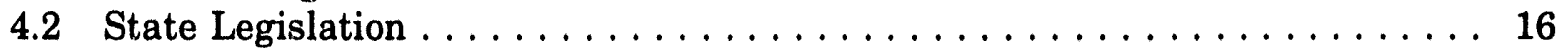

5 RESEARCH AND DEVELOPMENT NEEDS $\ldots \ldots \ldots \ldots \ldots \ldots \ldots \ldots$

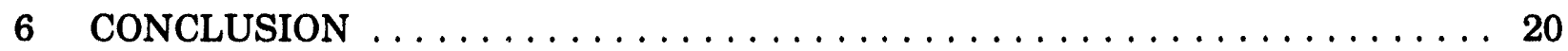

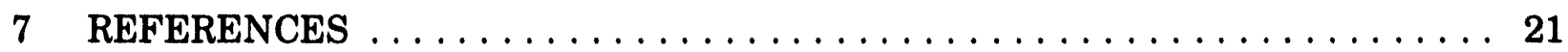




\section{TABLES}

1 Sensitivity of Lube Oil Prices to Crude Prices . . . . . . . . . . . . . . . . . . 12

2 Energy Required for Producing Lube Oil from Crude Oil and Used Oil . . . . . . . 14

3 Energy Conservation Comparison: Reprocessing versus Re-Refining . . . . . . 14

4 Estimates of Current and Potential Energy Savings from Used Oil

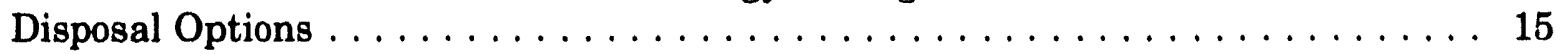

\section{FIGURES}

1 Used Oil Generation and Disposition in the United States in $1989 \ldots \ldots \ldots$

2 End Uses of Used Oil $\ldots \ldots \ldots \ldots \ldots \ldots \ldots \ldots \ldots \ldots$

3 Typical Process for Reprocessing Used Oil into Fuel . . . . . . . . . . . . 9

4 Process for Re-Refining Used Oil into Lubricant Base Stock . . . . . . . . . . 11 


\section{ACKNOWLEDGMENTS}

We are grateful to Stuart Natof, U.S. Department of Energy program manager, for his guidance and support. We also thank Dennis W. Brinkman of Safety-Kleen Corporation for his review and comments on this report. Finally, we would like to express our gratitude to Jane Andrew for technical editing. 


\title{
USED OIL DISPOSAL AND RECYCLING IN THE UNITED STATES
}

by

\author{
D.E. Karvelas and E.J. Daniels
}

\begin{abstract}
Used oil represents an important energy resource, which, if properly managed and reused, could lessen U.S. dependence on imported fuels. About 1.4 million gallons of used oil is generated annually in the United States. Of that total, about $70 \%$ is recycled: $57 \%$ is used as fuel and $12 \%$ is refined. In August 1992, the U.S. Environmental Protection Agency adopted standards for recycling of used oil, and many states also regulate used oil (six states list used oil as hazardous waste). This report reviews the sources of used oil and methods of disposition, focusing on reprocessing and rerefining. About $83 \%$ of the recycled used oil is reprocessed for use as fuel. However, concern about the level of lead in such fuel is increasing. Rerefining used oil is an environmentally friendly process that yields higher energy savings than reprocessing; however, it is more capital-intensive. Reprocessing used oil for use as fuel yields an energy savings (over disposal) of $131,130 \mathrm{Btu} / \mathrm{gal}$, while re-refining the oil for reuse as lube oil saves $180,000 \mathrm{Btu} / \mathrm{gal}$, an advantage of $48,870 \mathrm{Btu} / \mathrm{gal}$. However, further research is needed to enhance re-refining and to demonstrate the quality and competitiveness of its products.
\end{abstract}

\section{SUMMARY}

The annual generation of used oil in the United States is estimated at about 1.4 billion gallons. Used oil is defined as any oil that has been refined from crude oil, or synthetic oil, that has been used and as a result of such use is contaminated by physical or chemical impurities. About 63\% (873 million gallons) is generated by the automotive sector and $37 \%$ (512 million gallons) by the industrial sector. On the basis of U.S. Environmental Protection Agency (EPA) 1989 estimates, about 57\% (784 million gallons) of the used oil generated was reprocessed ${ }^{1}$ into fuel, $12 \%$ (165 million gallons) was re-refined, ${ }^{2} 13 \%$ (183 million gallons) was dumped in landfills and sewers by do-it-yourself(DIY) oil changers,

1 Oil reprocessing - the process of producing a fuel or fuel supplement from used oil by the application of mild cleaning methods, such as settling, filtration, centrifugal separation, and (sometimes) heating.

2 Oil re-refining - the process of cleaning and upgrading waste lubricating oil to produce a highquality base oil; the base oil is then blended with additives. The product of this process is called re-refined lubricating (lube) oil. 
about $16 \%$ (219 million gallons) was dumped by commercial automotive businesses, and $2 \%$ (28 million) was used for road oiling. Less than 6\% of the DIY-generated oil was recycled.

Used oil represents an important energy resource, and if it were properly managed and reused, it would lessen our dependence on imported fuels. It is estimated that every gallon of lubricating oil produced from re-refined used oil represents an energy savings of $48,000 \mathrm{Btu}$ (re-refining requires only about one-third the energy of refining virgin oil from petroleum crudes). Further, used oils dumped in landfills and sewers can potentially damage the environment and contaminate our water supplies. To assure the proper management of used oil, the federal government has recently implemented regulations and established standards for used oil management. In May 1992, EPA determined that used oils destined for disposal do not have to be listed as hazardous waste. This decision was based on EPA's conclusion that hazardous used oils were already regulated under the Resource Conservation and Recovery Act of 1976 (RCRA) as a result of the adoption of a more comprehensive toxicity characteristic. In August 1992, EPA promulgated a final decision for used oils that are recycled; the decision includes final management standards for used oil under RCRA, Section 3014. The standards established by EPA cover used oil generators, transporters, processors and re-refiners, burners, and marketers. DIY generators are not subject to the standards for used oil generators.

Currently, more than 14 states have enacted legislation with various levels of requirements for setting up used oil collection and management programs. Six states list used oil as hazardous waste, but some state regulations provide for delisting used oil if it meets required purity standards. In California's used oil management system, used oil is listed as hazardous waste at the time the commercial collector picks it up for shipment to a recycling plant or disposal facility. Thereafter, if the recycled oil meets the specified standards, it is automatically delisted from the hazardous waste system.

More than $83 \%$ of the recycled ${ }^{3}$ used oil ( 967 million gallons) is adapted for use as fuels. Such fuels contain approximately the same heating value as virgin oil. Before used oil can be burned as fuel, it must meet EPA (and sometimes more stringent local government) specification standards. Many used oils contain concentrations of metallic contaminants, which, if not reduced to EPA-specified levels, can cause adverse environmental effects. The most significant contaminant is lead. Current EPA regulations allow used oil with up to 100 parts per million (ppm) of lead to be burned for energy recovery in facilities that meet EPA regulations. The lead content in most of the currently recycled used oils is below the $100 \mathrm{ppm}$ limit. In a recent congressional hearing before the Committee on Energy and Natural Resources on a proposed bill (S. 2631, the Used Oil Energy Production Act), ${ }^{4}$ committee members and private sector participants expressed concerns about whether the

3 The term "recycled oil" any used oil that is reused, following its original use, for any purpose (including the purpose for which oil was originally used). So defined, the term includes oil that is re-refined, reclaimed, burned, or reprocessed.

4 S. 2631 was not enacted into law. It was designed to promote the refining, re-refining, and reprocessing of used lubricating oil into fuels and other petroleum products. A main feature of this act was the establishment of market-oriented incentives for recycling used oil, such as tradable credits. 
current lead specification level of $100 \mathrm{ppm}$ provides adequate protection for the public. The lead level in used oil fuels that are burned for heat recovery will likely continue to be an issue and will need to be addressed in the future.

About $12 \%$ of the used oil generated in 1989 was re-refined. The re-refining industry currently employs environmentally friendly, state-of-the-art re-refining processes, but new re-refining plants are capital-intensive. Because the equipment is expensive, plants have to be built with a large capacity to achieve some economy of scale. The economics of re-refining used oil is directly affected by the price of virgin crude oil. The transportation cost for collecting large volumes of used oil is also a major cost factor in re-refining. In the last decade, the industry declined in capacity, but new and more efficient plants were completed recently (1991) in California and Indiana, which should enable the industry to become more competitive. Many of these plants are designed to handle used oils classified as hazardous waste. In states such as California, where used oil is listed as hazardous (i.e., where a modified plan for listing used oil is applied), fuel processors may not be able to underbid re-refiners for used oil, because the fuel processors' costs have increased as a result of the additional capital investment necessary to qualify to process used oil that has been classified as hazardous waste.

This report also discusses the need for research to enhance used oil re-refining and address the public's concerns about the issue of burning used oil that contains lead. 


\section{GENERATION OF USED OIL}

Used oil is defined (40 CFR 260.10) as any oil that has been refined from crude oil, or any synthetic oil, that has been used and as a result of such use is contaminated by physical or chemical impurities. In virtually all lubricating and industrial applications, the performance of the oil deteriorates over time as oil additives break down and as contaminants build up in the oil. Eventually, the oil must be removed from service and replaced. Each of the thousands of specific oil applications is a source of use $d$ oil because of these routine replacements. Current estimates of the amount of used oil generated in the United States are based on the quantity of new oil sold annually to various application areas in the automotive and industrial sectors.

\subsection{SOURCES}

Used oils are classified into two broad categories: automotive and industrial. The sources of used oils within these two categories are as follows:

- Automotive

- Engine (crankcase) oils

- Transmission fluids

- Diesel oils

- Automotive hydraulic fluids

- Industrial

- Hydraulic

- Compressor (refrigeration)

- Engine (railroad diesel, marine, natural gas)

- Metalworking

- Process

\subsection{ESTIMATES OF VOLUME}

Annual sales of lubricating oils in the United States are estimated at about 2.2 billion gallons (Schroeder 1992). The volume of used oil generated annually in the United States is about 1.4 billion gallons (Joglekar 1992) (Figure 1). About 63\% ( 873 million gallons) of the used oil was generated by the automotive sector and $37 \%$ ( 512 million gallons) by industrial applications. In the automotive sector, do-it-yourself (DIY) oil changers generated 


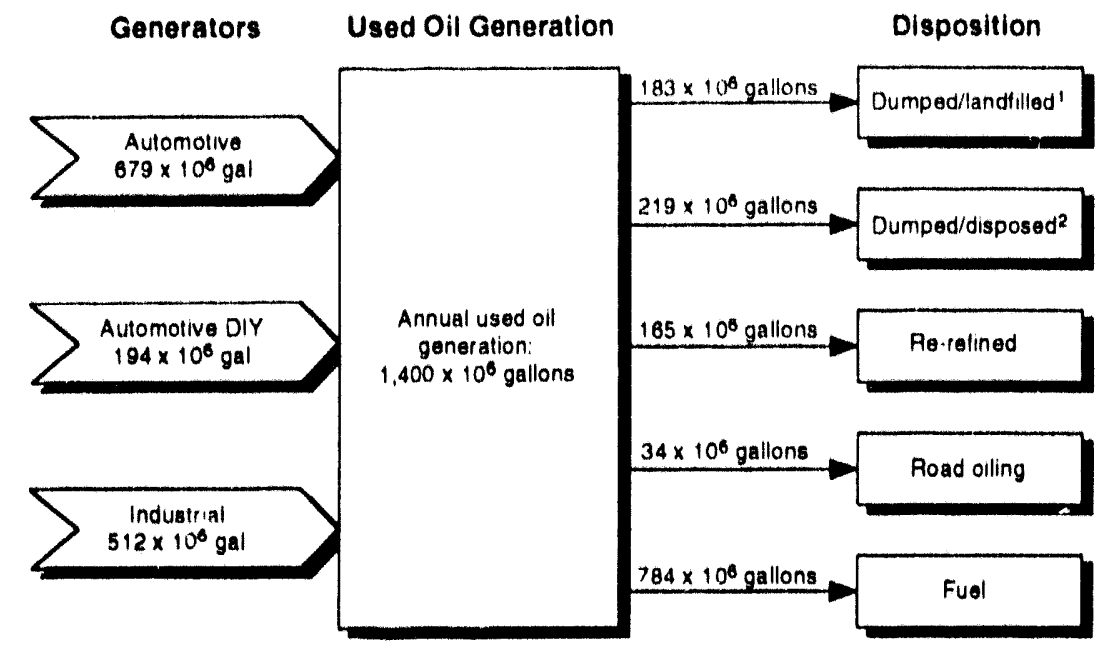

1. DIY.generated oil dumped in sewers, landtills, and on the Itnd

2. Commercially generated oil dumped of disposed of

FIGURE 1 Used Oil Generation and Disposition in the United States in 1989 (Source: Joglekar 1992)

$14 \%$ (194 million gallons) of the total. Generation rates for various oils also depend upon losses that occur during use or handling as a result of leakage, spillage, combustion, disposal with equipment, ${ }^{5}$ and incorporation into a finished product such as paint, putties, or rubber.

\subsection{GENERATORS}

A used oil generator is any perion whose act or process produces used oil or whose act first causes used oil to become subject to regulations. For example, generators include all persons and businesses, including government agencies, that produce used oil through commercial or industrial operations and vehicle services. The term also applies to persons, businesses, and agencies that collect used oil from households and DIY oil changers.

The U.S. Environmental Protection Agency (EPA) estimates (56 FR 48001 [Sept. 23, 1991]) that there are approximately 640,000 nonhousehold used oil generators, of which 358,000 are industrial generators (motor vehicles, piimary metals, chemicals, machinery, and others) and 282,000 are automotive generators (service stations, repair shops, quick lubes, car dealers, fleets, and others). A large portion of these generitors are small businesses. The number of DIY generators - people who change their own oil - may range from 40 million to 60 million households.

5 Includes the disposal of electrical, cooling, and hydraulic oils with decommissioned equipment containing these oils. 


\section{DISPOSITION OF USED OIL}

\subsection{COLLECTORS/TRANSPORTERS}

EPA estimates that the are about 380 collectors and transporters of used oil in the United States (56 FR 48001 [Sept. 23, 1991]). A used oil coilector/transporter is (1) any person or business that collects used oil from more than one generator or transporter or (2) a generator that transports shipments of more than 55 gallons of used oil and that transports the used oil off-site to another party or establishment for recycling, disposal, or continued transport. Other used oil generators, including DIY oil changers who transport less than 55 gallons of used oil to collection centers, are not included in the definition. In August 1992, EPA promulgated used oil management standards, which provide guidelines to collectors and transporters for managing used oil. These standards are intended to provide adequate protection for human health and for the environment.

\subsection{METHODS OF DISPOSITION}

EPA estimates (Joglekar 1992) that in 1989 approximately 57\% of the total amount of used oil generated was reprocessed and used for fuel, about $16 \%$ was dumped by commercial generators, $13 \%$ was dumped in landfills and sewers by DIY automotive oil changers, about $12 \%$ was re-refined, and $2 \%$ was used for road oiling. ${ }^{6}$ The Resource Conservation and Recovery Act of 1976 (RCRA) does not give EPA any authority to regulate waste generated by individuals or households (DIYs). Less than $6 \%$ of the DIY-generated used oils is recycled. ${ }^{7}$ Burning is the single largest end-use category for used oil. A breakdown of the end uses of used oil is shown in Figure 2.

Reprocessed used oils contain approximately the same heating value per gallon as virgin oil. However, many of the used oils contain high concentrations of metallic contaminants. Burning such oils without removing these contaminants can have adverse environmental effects. The most significant contaminant is lead. With the phase-out of lead in gasolines in the $1980 \mathrm{~s}$, lead concentrations in used oils from automotive sources have dropped considerably. The lead content in most of the currently recycled used oils has dropped to less than 100 parts per million (ppm) (Train 1992). Current regulations prohibit outright the burning of any used oil that is mixed with hazardous waste in nonindustrial

6 In September 1992, EPA decided to prohibit the use of used oil as a dust suppressant because of the inherent risk of contaminating water streams.

7 The term "recycled oil" means any used oil that is reused, following its original use, for any purpose (including the purpose for which oil was originally used). So defined, the term includes oil that is re-refined, reclaimed, burned, or reprocessed. 
boilers or furnaces. Current regulations classify $^{8}$ used oil destined for energy recovery as on- or off-specification, depending on whether it meets certain criteria. Today, the vast majority of used oil is on-specification (less than $100 \mathrm{ppm}$ lead). In addition, burning offspecification ${ }^{9}$ used oil in nonindustrial bjilers and furnaces is prohibited.

In the United States, used oil destined for use as fuel is most often reprocessed. A typical used oil reprocessor may incorporate a number of technically simple separation methods to remove most of the contaminants in the used oil (primarily water). Some of the process steps

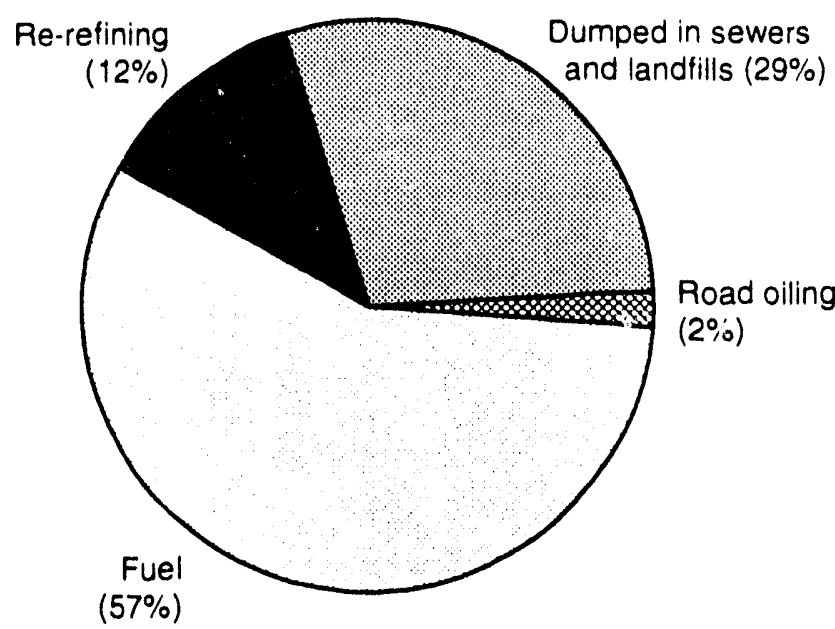

FIGURE 2 End Uses of Used Oil (Source: Joglekar 1992; data from 1989) used are settling, heating, dehydration, treating, and centrifuging. Depending on end-user specifications, reprocessors may blend the used oil with virgin oil. The technologies for used oil reprocessing range from simple filtering to a sophisticated method of distillation. A typical process currently used is shown in Figure 3.

\subsection{BURNING USED OIL AS FUEL}

In 1985, EPA promulgated a set of regulations that established a number of prohibitions and controls on the practice of burning used oil as fuel (50 FR 49164 [Nov. 29, 1985]). First, EPA prohibited outright the burning of any used oil that is mixed with hazardous waste in nonindustrial boilers or furnaces. Second, burning of used oil in nonindustrial boilers is also prohibited if the used oil contains more than $100 \mathrm{ppm}$ lead, $5 \mathrm{ppm}$ arsenic, $2 \mathrm{ppm}$ cadmium, $10 \mathrm{ppm}$ chromium, or $4,000 \mathrm{ppm}$ halogens. These limits, along with a minimum flash point requirement of $100^{\circ} \mathrm{F}$, constitute what is known as the used oil specification.

EPA currently estimates that approximately 784 million gallons of used oil are burned each year. Of this total, over $90 \%$ is burned in boilers and furnaces, $3 \%$ in diesel

8 Used oil fucl classification under RCRA.

9 Used oil that exceeds any of the following specification levels is considered to be "off-specification" under 40 CFR 266.4O(e): $100 \mathrm{ppm}$ lead, $5 \mathrm{ppm}$ arsenic, $2 \mathrm{ppm}$ cadmium, $10 \mathrm{ppm}$ chromium, $4,000 \mathrm{ppm}$ total halogens, and $100^{\circ} \mathrm{F}$ minimum flash point. 


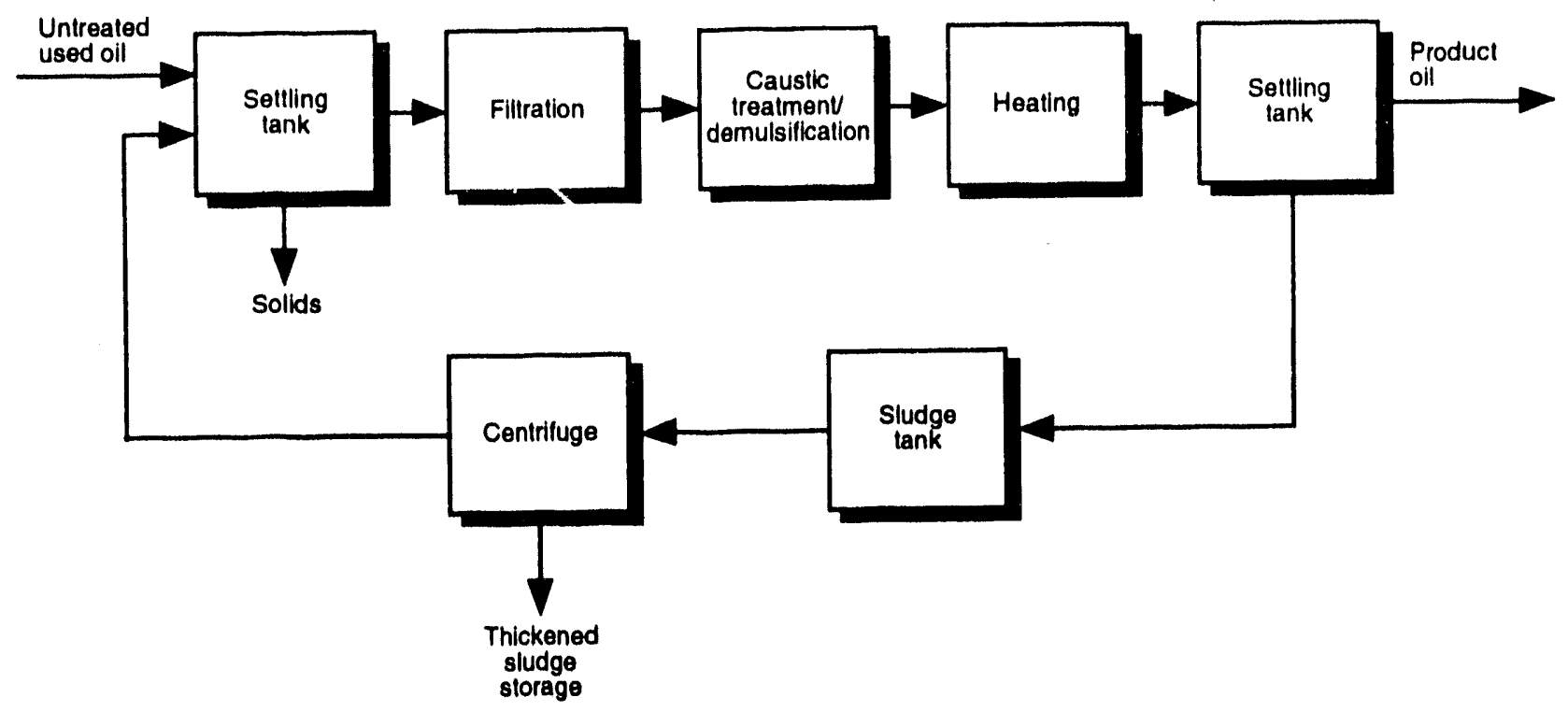

FIGURE 3 Typical Process for Reprocessing Used Oil into Fuel

engines, less than $1 \%$ in cement kilns, and about 6\% in space heaters (EPA regulations allow, under certain conditions, used oil generators to burn off-specification used oil on-site for energy recovery). EPA estimates that the used oil fuels burned annually contain a total of about $261,000 \mathrm{lb}$ of lead. Actual lead emissions will be lower because industrial and utility boilers are equipped with emission control systems.

In a recent hearing before the Committee on Energy and Natural Resources on S.2631, the Used Oil Energy Production Act (U.S. Senate 1992), committee members and other private sector participants raised the issue of potential hazards associated with burning used oil. Concerns were expressed about whether the current lead specification of $100 \mathrm{ppm}$ provides adequate protection to the public. EPA's position on this issue (Train 1992) was that EPA is developing a plan to reexamine the following important aspects of this issue: the risks associated with burning used oil, the protectiveness of the $100 \mathrm{ppm}$ lead specification level, the sources of lead in used oil, the need for emissions standards for used oil burners, and the proper levels of control necessary for units burning used oil. The issue of lead exposure remains high on the Agency's list of priorities, and EPA will continue to examine its regulations to ensure adequate protection of the environment and human health. A number of participants in the above hearing (including EPA staff members and representatives from the Natural Resources Defense Council, the Izaak Walton League of America, and the Hazardous Waste Treatment Council) expressed concerns about the potential hazards associated with burning used oil.

\subsection{RE-REFINING USED OIL}

Technically, used lubrication oil can be recycled in conventional crude oil refineries. Petroleum refining processes are generally adequate, with some minor modifications, for 
processing used oil; however, in practice, virgin crude refineries do not recycle used oil because metallic contaminants present in the used oil can adversely affect some key catalytic refining processes. In addition, used oils are characterized by a wide range of chemical compositions, and this inconsistency in quality makes it uneconomical to design and operate a virgin crude oil refining facility that can process large volumes of used oil. Thus, the job of converting used oil into high-quality base lubricating oil falls to what is known as the re-refining industry. The re-refining industry is currently small. According to EPA, in 1960 there were more than 150 companies producing more than 300 million gallons of re-refined oils annually (Chalhoub 1991). However, beginning in approximately 1965, the industry went into a steady decline. By 1988, there were just four operating plants and the volume had dropped to 67 million gallons. In 1989, about $12 \%$ (165 million gallons) (Joglekar 1992) of the used oil generated was re-refined. Several factors have attributed to the decline:

- Federal Trade Commission ruling requiring re-refined oil to be labeled.

- Elimination of excise tax that was benefitting the re-refined oil by 6 cents per gallon. Prior to 1965, lubricating oil made from crude oil was subject to a tax of 6 cents per gallon.

- High cost of environmental compliance.

- Lack of a proven process in the 1970 s to produce a re-refined oil equivalent in quality to a product produced from crude oil.

- Undercapitalization of small businesses.

By the late 1980 s, many of the factors that led to the decline of the industry had been reversed. The re-refining industry today employs efficient and environmentally friendly processes and is capable of producing lube base oil stocks to the same specifications as those for oils produced from virgin feedstocks. The environmentally unacceptable acid-clay re-refining process has been replaced by a vacuum distillation-hydrotreating process. This process has successfully eliminated the acid sludges and spent clays previously produced by re-refining. The vacuum distillation-hydrotreating technology was developed by the U.S. Department of Energy (DOE). Two recently constructed (1991) re-refining plants in Indiana ( 75 million gallons per year) and California ( 25 million gallons per year) employ this state-of-the-art technology. Figure 4 shows a typical modern used oil re-refining process.

For every gallon of used oil that is re-refined, $65 \%$ is made into two types of lube oils, while $10-15 \%$ is light ends or fuels, $10 \%$ is waste water, and $10 \%$ is bottoms or asphalt flux (Arner 1992). The lube oil is sold to lube oil blenders and compounders, who provide additives and then package the product for industrial and retail marketing. Some of the fuel is burned internally for the process needs, and excess fuel is sold to fuel companies. The asphalt flux may be sold to roofing manufacturers or to steel mills as fuel. 


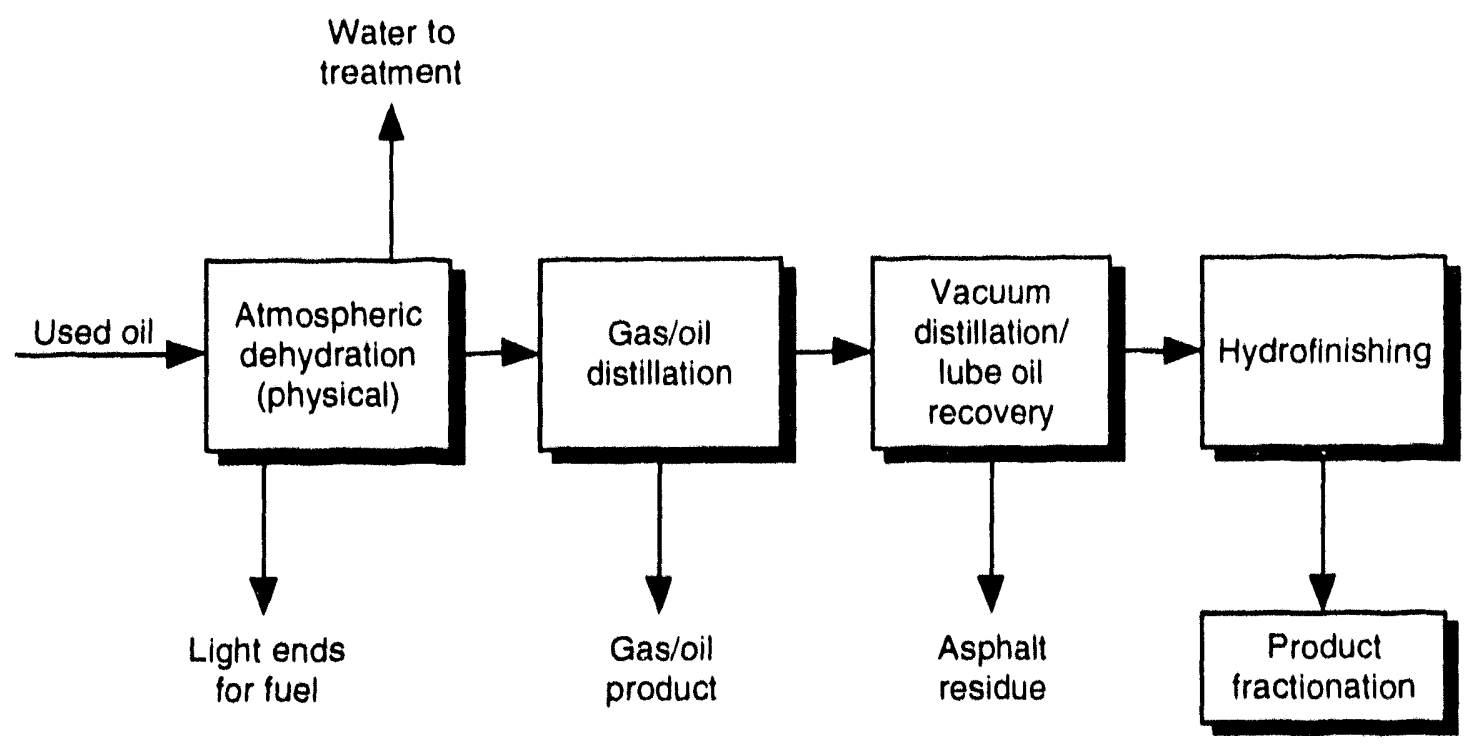

FIGURE 4 Process for Re-Refining Used Oil into Lubricant Base Stock

The new re-refining plant in Indiana is owned by Safety-Kleen Corporation. It has the largest capacity in the world and is designed to handle used oil that has been classified as hazardous waste. In 1992, EPA decided not to list used oil as hazardous waste, even though the re-refining industry had called for tougher standards. The Indiana plant would have gained the most if EPA had imposed more stringent standards, because it is designed to handle used oils that have been classified as hazardous.

The recently constructed plant in California already benefits from a California law that requires used oil to be handled as hazardous waste. In California, used oil is listed as hazardous waste at the time a commercial collector picks the oil up for shipment to a recycling or disposal facility. Thereafter, if the recycled oil meets protective numerical specifications, it is automatically delisted from the hazardous waste system and can be sold without reference to its former status as hazardous waste. The recycling and disposal facilities, however, are strictly regulated as managers of hazardous waste.

The economics of re-refining used oil is directly affected by the price of virgin crude oil. A recent study on the costs of producing lube oils from used oils and virgin oils (McKeagan 1992) indicates that both operations are at about break-even for crude oil prices as low as $\$ 13 /$ barrel (bbl) excluding transportation costs (Table 1). At higher crude oil prices, lube oils produced from used oil become more cost-competitive.

The cost of transporting used oil to a re-refinery and moving the finished product to the end users is a major economic barrier to re-refining used oil. Used oil is generated in small quantities by a large number of generators, and it is gathered at a great expense. It is estimated that every 100 miles of travel adds 5 cents per gallon to the cost of the oil. 
TABLE 1 Sensitivity of Lube Oil Prices to Crude Prices (\$/gal)

\begin{tabular}{lcccccc}
\hline & \multicolumn{2}{c}{ Crude Oil at $\$ 20.00 / \mathrm{bbl}$} & & \multicolumn{2}{c}{ Crude Oil at $\$ 12.00 / \mathrm{bbl}$} \\
\cline { 2 - 3 } \cline { 6 - 6 } \multicolumn{1}{c}{ Costs/Profit } & Virgin Lubes & Re-Refinery & & Virgin Lubes & Re-Refinery \\
\hline \multirow{2}{*}{ Feed } & $\$ 1.67$ & $\$ 0.23$ & & $\$ 1.00$ & $\$ 0.23$ \\
By-product credit & $(0.96)$ & $(0.14)$ & & $(0.58)$ & $(0.08)$ \\
Operations & 0.14 & 0.45 & & 0.13 & 0.44 \\
Total cost & 0.85 & 0.54 & & 0.55 & 0.59 \\
& & & & & 0.54 & 0.54 \\
Selling price & 0.90 & 0.90 & & -0.01 & -0.05 \\
Gross profit & 0.05 & 0.36 & & 0.05 \\
\hline
\end{tabular}

Source: Produced from data in McKeagan (1992).

Re-refining plants are capital-intensive, and because the equipment is expensive, plants have to be built with a large capacity to achieve some economy of scale.

Safety-Kleen's recently built plant in East Chicago, Indiana, has a design capacity of 75 million gallons per year. To collect the large volume of used oil required for this plant, the used oil collection trucks must drive long distances, which results in higher transportation costs. The typical cost of delivering used oil to re-refining plants in the United States ranges from -20 cents to +25 cents (Che 1991)

Fuel processors are major competitors of re-refiners. The fuel processor often has lower costs and usually can underbid the re-refiner. A fuel processing plant is technically simple and comparatively inexpensive because the fuel processor needs only to heat the oil, dehydrate it, and remove the lighter petroleum fractions. The re-refiner must dehydrate, distill, and finally finish the oil with the hydrogen process. Because fuel processing plants are inexpensive to build, they need not be built with large capacity. Today there are approximately 200 fuel processing plants across the country (Nolan 1991), compared to three re-refining plants (Chalhoub 1991). By having fuel processing plants spread throughout the country, oil to be recycled as fuel can be collected at low cost within a limited geographic area. Major burners of recycled oil are asphalt plants, and because asphalt plants are located in virtually in every county in the in the United States, the transportation cost for the finished product is also low. 


\section{ENERGY CONSERVATION CONSIDERATIONS}

Fuel derived from used oil has about the same energy content per pound as virgin oil. The energy content of virgin No. 6 fuel oil is about 149,000 Btu/gal. Assuming an average energy value for reprocessed used oil of 138,000 Btu/gal, the total energy value of the used oil generated annually in the United States is about 196 trillion Btu, or 0.2 Quad, which represents about $0.25 \%$ of the total U.S. energy consumption. Currently, about $57 \%$ of the used oil is reclaimed for fuel, about $12 \%$ is re-refined, and about $29 \%$ is dumped or landfilled. The used oil dumped or landfilled represents a loss of energy of about 57 trillion Btu annually.

The two principal commercial end products of the used oil recycling system are fuel and lube oil. In that system, far more fuel oil than lube oil is produced. As with many other recycling processes, recycling of used oil requires energy investments. The energy conservation potential of used oil recycling will depend on the market demand of the recycled end-products and the amount of energy required to produce the recovered products. To get a better perspective on the energy conservation potential of used oil recycling, we will provide a preliminary analysis of the process energy requirements for reprocessed oil and re-refined oil.

\subsection{REPROCESSING USED OIL AS FUEL}

On average, a gallon of reprocessed used oil, to be used as fuel, has an energy content of about 138,000 Btu. The energy required for producing one gallon of fuel oil from used oil is about 7,000 Btu (Mueller Associates, Inc., 1989). Therefore, the energy saved by reprocessing a gallon of used oil into fuel, rather than dumping it, is about $131,000 \mathrm{Btu}$ $(138,000 \mathrm{Btu}-7,000 \mathrm{Btu})$. Given that the energy content of virgin No. 6 fuel oil is about $149,000 \mathrm{Btu}$, every gallon of used oil reprocessed for use as fuel oil displaces about 0.9 gallon (131,000 Btu/149,000 Btu/gal) of virgin No. 6 fuel oil.

\subsection{RE-REFINING USED OIL AS LUBE OIL}

The energy content of re-refined and virgin lube oils is, on the average, approximately $140,000 \mathrm{Btu} / \mathrm{gal}$. The manufacture of re-refined or virgin lube oils also requires an expenditure of energy. Table 2 shows a comparison of the energy requirements per gallon of lube oil produced from used oil and from crude oil. As Table 2 shows, re-refined oil requires about one-third the process energy required to refine virgin lube oil from petroleum crudes. On the basis of these calculations, the energy content of virgin lube oil is $140,000 \mathrm{Btu} / \mathrm{gal}$ (intrinsic energy value) plus an energy investment of 78,000 Btu/gal (refining from crude oil) for a total of $218,000 \mathrm{Btu} / \mathrm{gal}$. 
In a typical re-refining process, there is a shrinkage of about $16 \%$ due to wastage (1\%) and to conversion to other energy products $(15 \%)$. To determine the energy savings resulting from re-refining a gallon of used oil instead of dumping it, we assume that one gallon of re-refined lube oil is substituted for a gallon of virgin lube oil with an energy content of $218,000 \mathrm{Btu} / \mathrm{gal}$. On the basis of the above assumptions, the energy savings per gallon of used oil that is rerefined will be $180,000 \mathrm{Btu} / \mathrm{gal}$.

\subsection{COMPARISON OF REPROCESSING AND RE-REFINING}

TABLE 2 Energy Required for Producing Lube Oil from Crude Oil and Used Oil

\begin{tabular}{lrr}
\hline & \multicolumn{2}{c}{$\begin{array}{c}\text { Energy Required } \\
\text { (Btu/gal) }\end{array}$} \\
\cline { 2 - 3 } $\begin{array}{c}\text { Energy } \\
\text { Source }\end{array}$ & Crude Oil & Used Oil \\
\hline Fuel oil & 42,600 & 17,500 \\
Steam & 28,500 & 4,900 \\
Power & 5,300 & 2,800 \\
Chemicals & 1,600 & 1,600 \\
& & \\
Total & 78,000 & 26,800 \\
\hline
\end{tabular}

Source: Emerson (1980).

From an energy conservation perspective (i.e., excluding economic, environmental, institutional, social, and other issues), re-refining of used oil as a substitute for virgin lube oil conserves more energy $(48,870 \mathrm{Btu} / \mathrm{gal}$ of used oil) than reprocessing used oil for use as fuel, as shown in Table 3.

Table 4 shows estimates of annual energy savings from current used oil disposal practices, including estimates of potential energy savings resulting from recycling all currently generated used oil through re-refining.

TABLE 3 Energy Conservation Comparison: Reprocessing versus Re-Refining

$\begin{array}{ll}\text { Re-refined lube oil energy savings over disposal } & =180,000 \mathrm{Btw} / \mathrm{gal} \\ \text { Reprocessed fuel energy savings over disposal } & =131,130 \mathrm{Btw} / \mathrm{gal} \\ \text { Re-refining advantage } & =48,870 \mathrm{Btw} / \mathrm{gal}\end{array}$


TABLE 4 Estimates of Current and Potential Energy Savings from Used Oil Disposal Options

\begin{tabular}{lccc}
\hline \multicolumn{1}{c}{$\begin{array}{c}\text { Disposition of } \\
\text { Used Oil }\end{array}$} & $\begin{array}{c}\text { Quantity } \\
\text { Generated/Disposed } \\
\text { (million gaVyear) }\end{array}$ & $\begin{array}{c}\text { Current Energy } \\
\text { Savings through } \\
\text { Recycling } \\
\text { (trillion Btw/year) }\end{array}$ & $\begin{array}{c}\text { Potential Energy } \\
\text { Savings }\end{array}$ \\
(trillion Btw/year)
\end{tabular}

If re-refined to lube oil stock. 


\section{REGULATIONS}

\subsection{FEDERAL REGULATIONS}

Since 1980, a number of pieces of legislation have been enacted in an attempt to resolve the regulatory and liability issues associated with the disposal of used oil. Final listing decisions on used oil were preceded by EPA's published (September 1991) Supplementary Notice of Proposed Rulemaking for the identification and listing of used oil and for management standards for recycled used oil. In this notice, three options were presented for identifying used oil as a hazardous waste: (1) list used oils as proposed in 1985 (50 FR 49239), (2) list categories of used oil that were found to be typically and frequently hazardous, and (3) do not list used oil as hazardous waste but rely on management standards. Commenters overwhelmingly supported the third option. Many of these commenters suggested that regulating used oil as hazardous waste would have a negative effect on the entire used oil recycling system, especially voluntary DIY programs. Commenters emphasized the need to encourage recycling through education, proper collection, and strong management standards.

In May 1992, after considering commenters' input, EPA determined that used oil destined for disposal does not have to be listed as hazardous waste. This decision was based on EPA's conclusion that hazardous used nil was already regulated under the RCRA as a result of the adoption of a more comprehensive toxicity characteristic. In addition, EPA took into account the regulatory programs that already exist for controlling used oil.

In August 1992, EPA promulgated a final listing decision for used oils that are recycled. The decision included final management standards for used oil under the RCRA, Section 3014. EPA's decision not to list recycled used oil as hazardous waste was based on the technical criteria provided in Sections 1004 and 3001 of the RCRA and in 40 CFR 261.11(a)(1) and 261.11(u)(3). These standards cover used oil generators, transporters, processors and re-refiners, burners, and marketers. DIY generators or private individuals who generate used oil through the maintenance of their vehicles are not subject to the used oil generator standards.

\subsection{STATE LEGISLATION}

In 1991, 28 states had proposed some type of legislation on used oil recycling. Legislation has passed in 14 states with various levels of requirements for setting up used oil collection and management programs. Currently, six states list used oil as hazardous waste: California, Massachusetts, Missouri, New Jersey, Rhode Island, and Vermont.

California's used oil regulation and collection system is currently viewed as one of the most successful state programs for managing used oil. The state of California has adopted a modified listing approach in which used oil is managed as hazardous waste unless it already meets certain purity standards or until it has been recycled to meet these 
standards. The state purity standard for lead is $50 \mathrm{ppm}$, compared to the federal used oil burning standard of $100 \mathrm{ppm}$. The state's regulations also require that heavy metals be removed instead of diluted, and recycled oils are required to contain lower levels of lead. In brief, the California used oil management system approach lists used oil as hazardous waste at the point that a commercial collector picks up the oil for shipment to a recycling plant or disposal facility. Thereafter, if the recycled oil meets the specified standards, it is automatically delisted from the hazardous waste system and can be sold without reference to its former status as hazardous waste. The recycling and disposal facilities, however, are strictly regulated as managers of hazardous waste. 


\section{RESEARCH AND DEVELOPMENT NEEDS}

In the past, research and development (R\&D) efforts were concentrated on the development of cost-effective and environmentally acceptable used oil recycling technologies. Much of this research was funded by the DOE, EPA, National Bureau of Standards (now the National Institute of Standards and Technology), and Department of Defense. In the 1980s, federal funds for research to enhance used oil recycling were cut substantially, and during that decade, the used oil recycling industry did not progress technologically. In the late 1980s, more stringent regulations on used oil handling and disposal were proposed by federal and state agencies, and these actions increased interest in defining and establishing economically viable and environmentally acceptable used oil collection and disposal plans. In the 1980s, EPA and the industry worked to identify and characterize used oil, and, in the private sector, construction began on several recycling facilities that used technologies developed in the previous decade. In the early $1990 \mathrm{~s}$, the re.refining industry has been consolidated to a few operators that have large capacities and technologically advanced refining facilities; however, their share of the total recycled used oil is small (less than 175 million gallons per year). The re-refining industry is capable of producing products that are substantially similar in most qualitative aspects to lubricants derived from virgin oil.

In recent hearings in Congress on proposed legislation for enhancing used oil recycling, concerns were raised about the burning of used oil and its impact on the environment. The lead in used oil is of major concern. Specifically, the current regulations set an upper specification level of $100 \mathrm{ppm}$ for used oil to be burned in nonindustrial burners. In the future, the lead level in used oil fuels might need to be reduced considerably. EPA has indicated that additional evaluation of the costs and risks of a lower level of lead would be pursued in a future rulemaking. To address this emerging issue in used oil recycling, it would be appropriate for DOE to conduct some preliminary R\&D at this time to assess the cost-effectiveness of current technologies for reducing or eliminating the lead contained in used oils and to identify lead removal technology R\&D needs.

Current industry R\&D activities for enhancing used oil re-refining are concentrated primarily in demonstrating that re-refined used oil products meet adequately and consistently the quality of competing products made from virgin oils. The following areas for R\&D have been suggested (Brinkman 1992):

- Analytical methods development. As the regulatory requirements expind to include more compounds at lower levels, there is a critical neel for better analysis methods that are practical for the typical used oil recycler. Most such recyclers cannot afford the sophisticated analytical equipment cited in the literature, and most methods are designed for cleaner and less complicated matrices than used oil. Without these analytical capabilities, many recyclers may be forced out of business. Specific analytical parameters that would be of interest are halogenated 
solvents, polychlorinated biphenyls in the presence of interfering compounds, and toxics and carcinogens at threshold limit values.

- Uses of recycling by-products. Research is needed on the use of byproducts, particularly in two promising areas: (1) identifying the key properties of distillation bottoms and using these data to develop goodquality asphalt extender and (2) evaluating the economic and environmental option of burning the light ends from the used oil recycling process.

- Industrial lubricants recycling. Research is needed to update information on the types and quantities of lubricants being used by industry, to define which streams can be blended for use within current recycling technologies, and to determine which streams would benefit from in house reclamation/enhancement filtration systems and which ones lack viable recycling options. Such research should generate detailed analytical information on each type of stream to document the extent of hazardous waste contamination.

- DIY oil collection. The economics of used oil recycling has changed radically since the earlier studies. Civic groups have been removed as likely contributors, since used oil now has a negative value in the marketplace. Research should be done to identify possible roles for industry and government in getting access to DIY oil and to determine the extent to which quick-lube services have cut into the DIY volume. 


\section{CONCLUSION}

It is estimated that approximately 1.4 billion gallons of used oil is generated annually in the United States. The major sources of used oil generation are automotive and industrial users of lubricating oil. More than 70\% of the used oil generated annually is heing recycled, primarily as fuel. Re-refining of used oil to lubricating oil presents the highest energy conservation potential, but historically this type of used oil recycling has not proven to be economically viable in many parts of the country because of declining crude oil prices, the high cost of re-refining technologies, and transportation costs for collecting large quantities of used oil. Federal and state regulations have also affected the economics of rerefining used oil. In May 1992, EPA determined that used oils destined for disposal do not have to be listed as hazardous waste. This decision did not help the economics of existing modern re-refining facilities, which are designed to process used oil classified as hazardous waste. In some states, such as California, state regulations on used oil management are much more stringent, compared to federal regulations. As a result, re-refining of used oil has become more cost-competitive.

Recycling of used oil for use as fuel has been the least-cost option for disposing of used oil. Current regulations set limits on the level of metallic contaminants in used oil burned for energy recovery. The most significant contaminant is lead. Currently, EPA regulations prohibit the burning of used oil in nonindustrial boilers if the used oil contains more than $100 \mathrm{ppm}$ of lead. Recently, some private organizations and federal government representatives have raised the issue of potential hazards associated with burning used oil. In particular, concerns have been expressed about the current lead specification of $100 \mathrm{ppm}$ and whether this threshold provides adequate protection to the public. EPA has indicated that additional evaluation of the costs and risks of a lower level of lead would be pursued in a future rulemaking.

Currently available technologies for reprocessing used oil for use as fuel and for re-refining it into lubricating oils ure adequate for meeting the industry's needs. The costeffectiveness of current technologies for recycling used oil will depend, in the future, on the requirements of new regulations that will be implemented by federal and state governments. Further, the cost of virgin crude oil will also have a major impact on the economics of re-refining used oil. The lead in used oil is of major concern because of the potential health hazards when it is burned for energy recovery. The lead issue will need to be researched further to assess its impact on the environment. To address this emerging issue in used oil recycling, it would be appropriate for DOE to conduct some preliminary R\&D at this time to assess the cost-effectiveness of current technologies for reducing or eliminating the lead contained in used oils and to identify R\&D needs in lead removal technology. 


\section{REFERENCES}

Arner, R., 1992, "Used Oil Recycling Markets and Best Management Practices in the United States," presented at the Nutional Recycling Congress, held in Boston, Mass., Sept. 15, 1992.

Brinkman, D.W., 1992, personal communication from Brinkman (Safety-Kleen Corporation, Elk Grove Village, Ill.) to D. Karvelas (Argonne National Laboratory, Argonne, Ill.), Oct. 12, 1992, citing a letter from Brinkman to A. Schroeder (U.S. Environmental Protection Agency, Conservation/Industrial Programs), April 24, 1990.

Chalhoub, J., 1991, "Re-refining in the USA," Proceedings of the 6th International Conference on Used Oil Recovery and Reuse: Re-refining Rebirth, sponsored by the Association of Petroleum Re-refiners, held in San Francisco, Calif., May 28-31, 1991, pp. 67-69.

Che, S., 1991, "Update of KIT Relube Process," Proceedings of the 6th International Conference on Used Oil Recovery and Reuse: Re-refining Rebirth, sponsored by the Association of Petroleum Re-refiners, held in San Francisco, Calif., May 28-31, 1991, pp. 157 169.

Emerson, H.R., 1980, The Advantage of Used Oil Re-Refining, prepared for Bartlesville Energy Technology Center, Bartlesville, Okla., May.

Joglekar, R., 1992, personal communication from Joglekar (U.S. Environmental Protection Agency, Office of Solid Waste, Characterization and Assessment Division) to D. Karvelas (Argonne National Laboratory, Argonne, Ill.), Dec. 15.

McKeagan, D., 1992, "Economics of Rerefining Used Lubricants," Lubrication Engineering, May, pp. 418-423.

Mueller Associates, Inc., 1989, Waste Oil: Reclaiming Technology, Utilization and Disposal, Noyes Data Corporation, Park Ridge, N.J.

Nolan, J., 1991, "Fuel Processing as Used Oil Recycling," Proceedings of the 6th International Conference on Used Oil Recovery and Reuse: Re-refining Rebirth, sponsored by the Association of Petroleum Re-refiners, held in San Francisco, Calif,, May 28-31, 1991, pp. 129-132.

Schroeder, M., 1992, testimony by M. Schroeder, Used Oil Encrgy Production Act: Hearing on S.2631 to Promote Energy Production from Used Oil, Senate Committee on Energy and Natural Resources, 102nd Congress, 2nd session, May 20, p. 17.

Train, C., 1992, testimony by C. Train (U.S. Environmental Protection Agency), Used Oil Energy Production Act: Hearing on S.2631 to Promote Energy Production from Used Oil, Senate Committee on Energy and Natural Resources, 102nd Congress, 2nd session, May 20, p. 21. 
U.S. Senate, 1992, Used Oil Energy Production Act: Hearing on S.2631 to Promote Energy Production from Used Oil, Senate Committee on Energy and Natural Resources, 102nd Congress, 2nd session, May 20. 

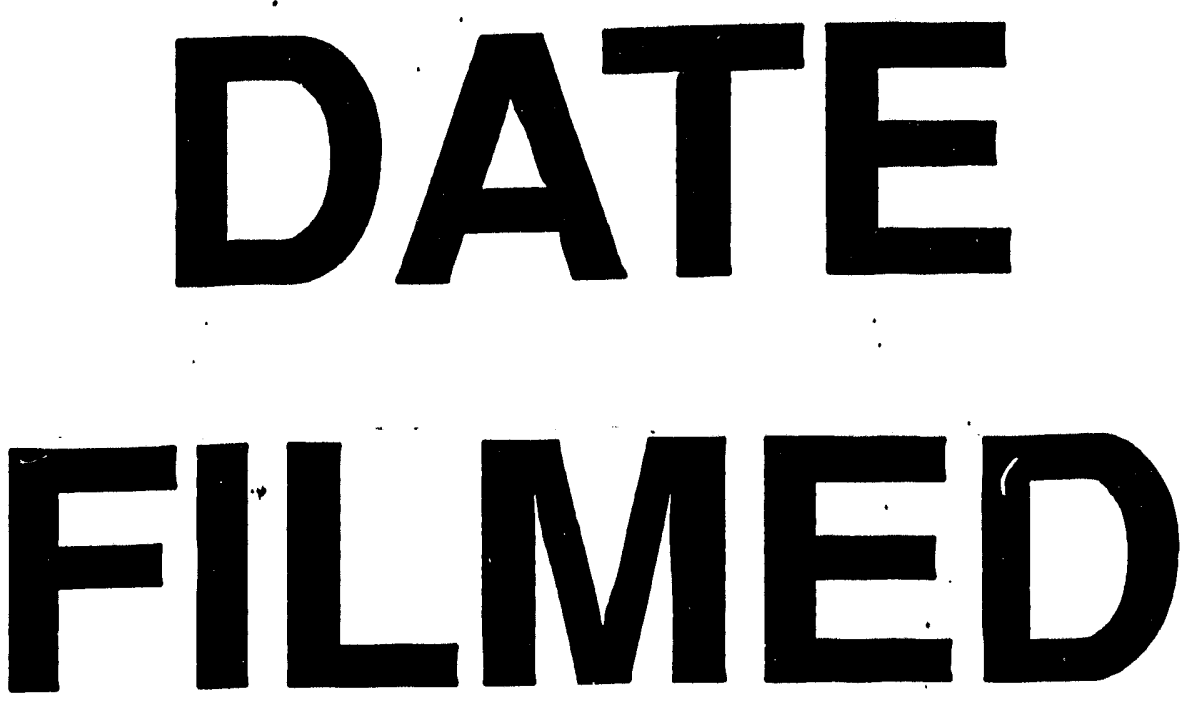

$12 / 3 / 93$
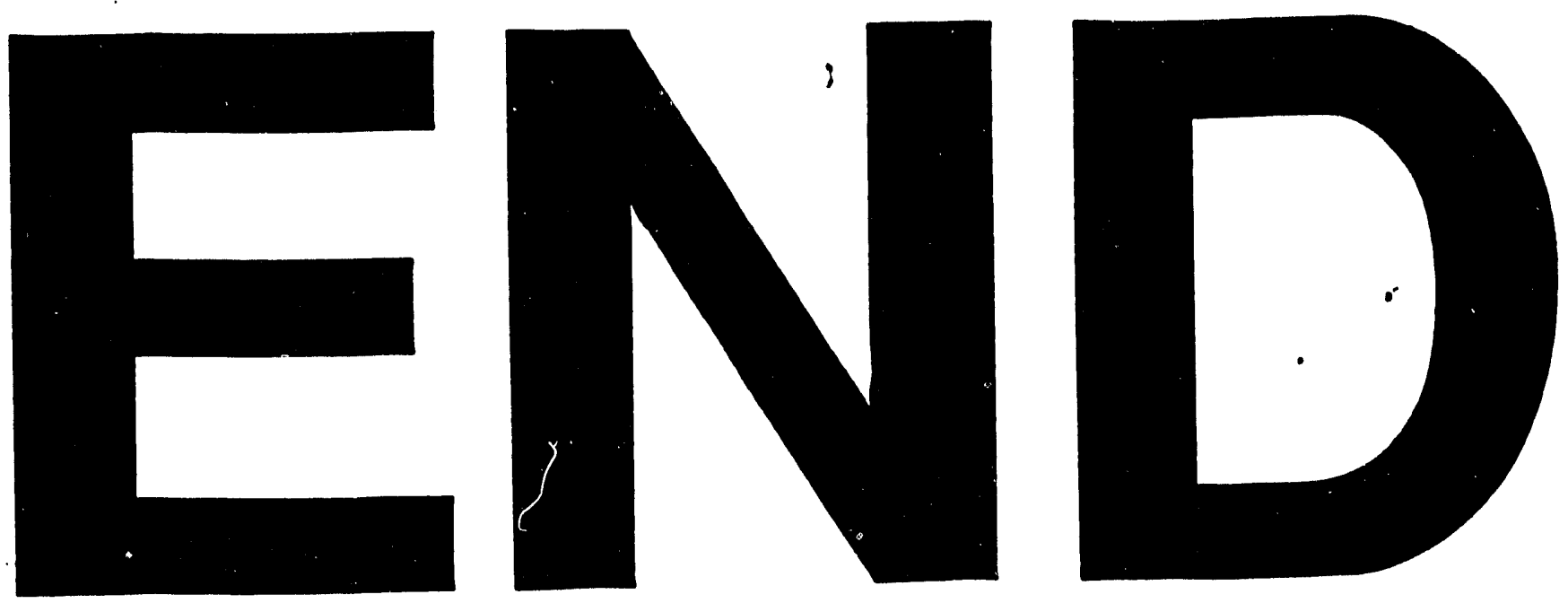


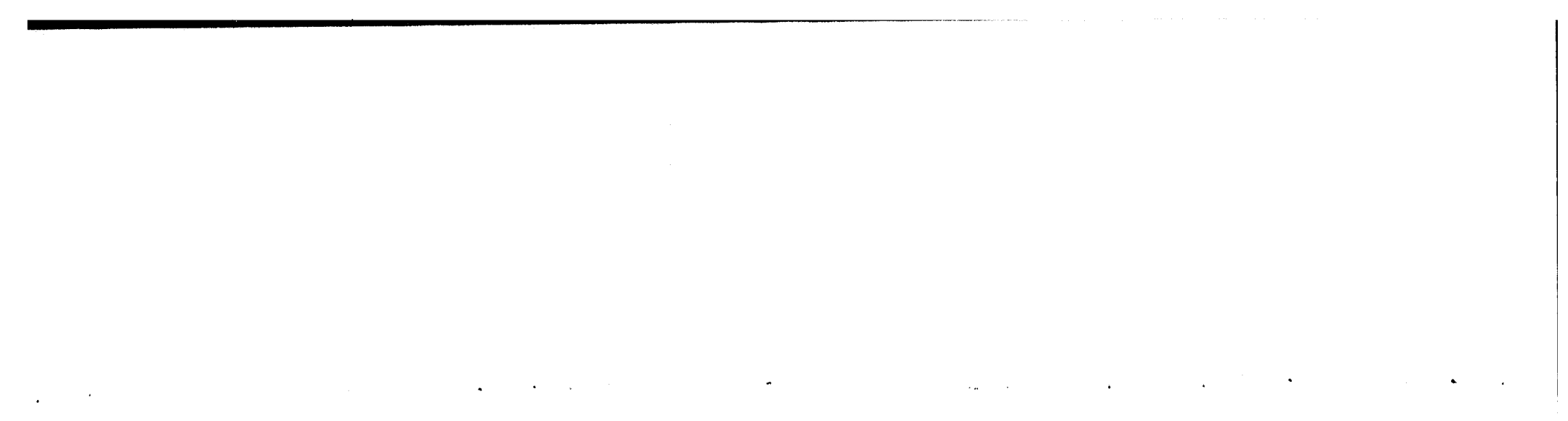

